Rev. Josef Spindelböck ${ }^{1}$

https://orcid.org/0000-0002-4563-3456; josef@spindelboeck.net

ITI Catholic University in Trumau (Austria)

\title{
Truth and Error of Conscience According to the Magisterium of the Church
}

\begin{abstract}
The relation of truth and error in conscience according to the newer actual Magisterium of the Church is the theme of this article, following a hermeneutic of reform in continuity (Benedict XVI). Emphasis is given first on Veritatis splendor by Pope John Paul II, then on Humanae vitae by Pope Paul VI and finally, in a special way, to Amoris laetitia by Pope Francis. A focus is laid on the dimension of virtue education since this helps the persons involved not only to grasp the truth of relevant moral values but also to realise morally good acts with the help of Divine grace. Even in situations of personal limitation, there is always a light of God telling the person how to know and do the good.
\end{abstract}

Keywords: conscience, Humanae vitae, Amoris laetitia, Veritatis splendor

\section{Streszczenie}

Prawda i błąd sumienia według Magisterium Kościoła

Tematem artykułu jest relacja prawdy i błędu w sumieniu według aktualnego Magisterium Kościoła, zgodnie z hermeneutyką reformy w ciągłości (Benedykt XVI). Analizie poddane zostały następujące dokumenty źródłowe: najpierw Veritatis splendor Jana Pawła II, następnie Humanae vitae Pawła VI i wreszcie, w sposób szczególny, Amoris laetitia papieża Franciszka. W centrum uwagi znajduje się wychowanie do cnoty, ponieważ pomaga ono osobom zaangażowanym nie tylko w zrozumieniu prawdy o istotnych wartościach moralnych, ale także w urzeczywistnianiu, z pomocą łaski

1 Rev. Josef Spindelböck - is a diocesan priest of St Pölten (Austria) who belongs to the clerical association "Gemeinschaft vom heiligen Josef". At present time he is ordinary professor for Moral Theology and Ethics at the Philosophisch-Theologische Hochschule St. Pölten and extraordinary professor at the International Theological Institute (ITI) Catholic University in Trumau (Austria). 
Bożej, dobrych moralnie czynów. Nawet w sytuacji osobistego ograniczenia zawsze istnieje światło Boże, które podpowiada człowiekowi, jak poznawać i czynić dobro. Słowa kluczowe: sumienie, Humanae vitae, Amoris laetitia, Veritatis splendor

\section{The Fundamental Role of Conscience According to Veritatis splendor and Humanae vitae}

Based on important post-Vatican II-documents of the Magisterium of the Church, it seems adequate to ask for the very nature of conscience and its relation to truth. Three main documents will be compared, namely the Encyclical Letters Humanae vitae by Pope Paul VI, ${ }^{2}$ Veritatis splendor by Pope John Paul $\mathrm{II}^{3}$ and the Postsynodal Apostolic Exhortation Amoris laetitia by Pope Francis. ${ }^{4}$

A hermeneutic of reform in continuity is followed, ${ }^{5}$ since the subject of the Magisterium remains identical in the course of Church history. The relevant subject is not this or that Pope, this or that bishop or a group of bishops, but the true subject of authentic teaching is the Church as such who teaches in the name of Christ. ${ }^{6}$

Humanae vitae gave clear instruction to married couples how to regulate fertility. ${ }^{7}$ Only a recourse to the infertile periods of the woman

2 Paul VI, Encyclical letter Humanae vitae (= HV) on the regulation of birth, July 25th, 1968, Latin text in Acta Apostolicae Sedis (= AAS) 60 (1968), p. 481-503, English translation in The Pope Speaks, 13 (Fall. 1969), p. 329-346.

3 John Paul II, Encyclical letter Veritatis splendor (=VS) regarding certain fundamental questions of the Church's moral teaching, August 6th, 1993, Latin text in AAS 85 (1993), p. $1133-1228$.

4 Francis, Post-synodal Apostolic Exhortation Amoris laetitia (= AL) on love in the family, March 19th, 2016, Latin text in AAS 108 (2016), p. 311-446.

5 "On the one hand, there is an interpretation that I would call 'a hermeneutic of discontinuity and rupture'; it has frequently availed itself of the sympathies of the mass media, and also one trend of modern theology. On the other, there is the 'hermeneutic of reform', of renewal in the continuity of the one subject-Church which the Lord has given to us. She is a subject which increases in time and develops, yet always remaining the same, the one subject of the journeying People of God." (Benedict XVI, Address to the Roman Curia offering them his Christmas greetings, 22.12.2005).

6 Cf. Vatican Council II, Dogmatic Constitution on the Church Lumen gentium, 21.11.1964, no. 25.

7 "Therefore We base Our words on the first principles of a human and Christian doctrine of marriage when We are obliged once more to declare that the direct interruption of the 
is allowed. ${ }^{8}$ Responsible parenthood "concerns the objective moral order which was established by God, and of which a right conscience is the true interpreter," Pope Paul VI formulated. ${ }^{9}$ Therefore, Humanae vitae grounds on a correct understanding of conscience, in the context of its relation with the objective truth of moral normativity. ${ }^{10}$

In the reception of the encyclical Humanae vitae, there were different and even contrasting statements and declarations, both by secular people, by lay believers, by experts in theology and philosophy, and by various bishops and conferences of bishops. Some statements expressed a general appreciation of the document but also showed understanding and sympathy for those who were in dissent with the teaching of the Church regarding the strict verdict on contraception. In Austria it was the declaration of the bishops given in Maria Trost from September $22^{\text {nd }}$, 1968, and in Germany it was the declaration of Königstein from August $30^{\text {th }}, 1968 .{ }^{11}$ These statements of the bishops were intended to help dissenters in reconsidering their own position and correcting it in some time. But the effects were often in the contrary direction: The declarations of the bishops were used by Humanae vitae critics to legitimate their dissent from this teaching of the Church, and one main argument was that of conscience. Conscience was established as an authority in contrast to the living Magisterium of the Church, and those advocates no longer spoke of an erroneous conscience but rather of an erroneous Magisterium of the Church.

generative process already begun and, above all, all direct abortion, even for therapeutic reasons, are to be absolutely excluded as lawful means of regulating the number of children. Equally to be condemned, as the magisterium of the Church has affirmed on many occasions, is direct sterilization, whether of the man or of the woman, whether permanent or temporary. Similarly excluded is any action which either before, at the moment of, or after sexual intercourse, is specifically intended to prevent procreation - whether as an end or as a means." (HV 14).

8 Cf. HV 16.

9 HV 10.

10 Cf. C. Schulz, Die Enzyklika "Humanae vitae" im Lichte von "Veritatis splendor". Verantwortete Elternschaft als Anwendungsfall der Grundlagen der katholischen Morallehre, St. Ottilien 2008.

11 Cf. K. Ebner, M. Mesner, Attempted Disobedience: "Humanae vitae" in West Germany and Austria, in: The Schism of '68. Catholicism, Contraception and "Humanae Vitae" in Europe, 1945-1975, eds. A. Harris, London 2018, p. 121-158. 
Therefore, Pope John Paul II reminded the faithful and the theologians on various occasions of the correspondence between conscience and truth, and of the moral obligation of the faithful to form their consciences according to the teaching of the Church. Both in the Catechism of the Catholic Church ${ }^{12}$ and in the Encyclical Letter Veritatis splendor Pope John Paul II clarified the true function of conscience against the challenges of subjectivism and relativism.

He did so by following the statement of Vatican Council II in Gaudium et spes on "The dignity of the moral conscience." ${ }^{13}$ The passage includes observations from personal experience, philosophical aspects, and theological interpretations. All this is in conformity with the solid fundament of Holy Scripture and the great fathers and doctors of the Church, such as Thomas Aquinas and Alphonsus Maria de Liguori. It clearly shows the orientation of conscience to the objective truth of morality which can be known both by reason (in natural moral law) and by faith in divine revelation (in the revealed law of old and New Testament). A twofold error in conscience is possible: without guilt and with guilt.

In contrast to the teaching of Vatican Council II, there are philosophical and theological concepts of conscience which deny the very possibility of error by replacing the conformity with truth with subjective authenticity. ${ }^{14}$

In the Catechism of the Catholic Church conscience is described in the following way: "The dignity of the human person implies and requires uprightness of moral conscience. Conscience includes the perception of the principles of morality (synderesis); their application in the given circumstances by practical discernment of reasons and goods; and finally judgment about concrete acts yet to be performed or already performed. The truth about the moral good, stated in the law of reason, is recognized practically and concretely by the prudent judgment of conscience.

12 Cf. Catechism of the Catholic Church, Second Edition, Vatican 1997 (= CCC), nos. 1776-1802.

13 Vatican Council II, Pastoral Constitution on the Church in the modern world Gaudium et spes, 7.12.1965, no. 16.

14 Cf. VS 32. 
We call that man prudent who chooses in conformity with this judgment." ${ }^{15}$ According to this statement, there are three functions of conscience which belong together, namely "synderesis," "syneidesis" and prudential judgment." 16

Following Veritatis splendor, conscience "in its primordial reality" should be described "as an act of a person's intelligence, the function of which is to apply the universal knowledge of the good in a specific situation and thus to express a judgment about the right conduct to be chosen here and now."17

Conscience is always oriented towards objective truth. This means, that the possibility and reality of error in conscience does not deny its orientation towards truth but confirms it and shows the necessity of ongoing formation of conscience according to the objective demands of truth. ${ }^{18}$ An invincible error of conscience which might not be culpable could result in a morally evil act.

The virtues should help to stay on the path of organic development and should contribute to the formation of conscience. The virtues both natural and theological establish some connaturality with the moral good. In this way, it becomes a second nature of man - namely a habit to know the good and to do it. "It is the 'heart' converted to the Lord and to the love of what is good which is really the source of true judgments of conscience." ${ }^{19}$

The view of Veritatis splendor is not a legalistic and minimalistic approach but shows a path of growth and formation. The direction is also

15 CCC 1780.

16 Thomas Aquinas dealt with „synderesis” in STh I q.79 a.12, with „syneidesis” in a.13 and with "prudentia“ in STh II-II q. 47-56. Cf. E. Schockenhoff, Wie gewiss ist das Gewissen? Eine ethische Orientierung, Freiburg 2003, ebook 2016, 102 ff.

17 VS 32.

18 "Conscience is not an infallible judge; it can make mistakes. However, error of conscience can be the result of an invincible ignorance, an ignorance of which the subject is not aware and which he is unable to overcome by himself. The Council reminds us that in cases where such invincible ignorance is not culpable, conscience does not lose its dignity, because even when it directs us to act in a way not in conformity with the objective moral order, it continues to speak in the name of that truth about the good which the subject is called to seek sincerely" (VS 62).

19 VS 63. 
followed by Pope Francis in "Amoris Laetitia," and this might seem surprising for those who erroneously conclude from the mere absence of quotations or references to Veritatis splendor in Amoris laetitia, that the latter would contradict the former.

\section{Forms of error in conscience}

On the basis of these statements, there are two forms of error in conscience which must be distinguished. ${ }^{20} \mathrm{~A}$ correctly formed judgment of conscience regarding a concrete moral act has two elements: a judgment regarding a fact and a judgment about moral values and moral normativity. Different forms of error could appear:

- First, there might be a deficit of knowledge or an error in the cognition of facts. Human knowledge here on earth necessarily remains imperfect; man has a moral obligation to know the morally relevant facts. But the human person must also accept that he or she is not always able to know those facts in a complete and precise way. Therefore, man is only obliged to strive for so called moral certainty which is not absolute certainty but sufficient for acting in a morally good way. ${ }^{21}$

- Second, there might be a deficit, an error or even a blindness in the cognition of moral values and moral norms..$^{22}$ If a person doesn't resist the temptations of pride and concupiscence, the perspective of the cognition of moral values is darkened. ${ }^{23}$

20 Cf. J. Spindelböck, Gewissen und Gewissensirrtum aus ethischer Perspektive, "Imago Hominis" 25 (2018) H. 1, p. 35-45.

${ }_{21}$ The question of prudential formation of conscience in contingent matters becomes a challenge of how to deal with the possibility of error. There seems to be some sort of "fuzzy logic" in it.

22 A problematic historic context might exercise such an influence on the consciences of even faithful, pious persons that their judgment becomes blind in some point (cf. Joseph Cardinal Ratzinger, Dokumentation "Die geheime Inquisition - Feuer des Glaubens" (1/3), Österreichischer Rundfunk (= ORF) III, 31.10.2018.

${ }_{23}$ Cf. Dietrich von Hildebrand, Ethik, Stuttgart o.J., 2. Auflage, p. 435 ff; p. $445 \mathrm{ff}$ and p. $455 \mathrm{ff}$; Dietrich von Hildebrand, Sittlichkeit und ethische Werterkenntnis. Eine Untersuchung über ethische Strukturprobleme, Vallendar-Schönstatt 1982, 44 ff. 


\section{The role and function of conscience according to Amoris laetitia}

It will now be asked for the concept of conscience used in Amoris laetitia and about the question of an erroneous conscience and its practical consequences described there. The method will follow the ductus of this document and look for relevant passages. Not only the term "conscience" is in its approach but the whole context and meaning of special passages.

AL represents and reveals a change of perspective but not a change of paradigms. The perspective is personal and pastoral; it is subjective but not subjectivist. The objective aspects of dogma and moral life are present and must be acknowledged. John Paul II and Benedict XVI have equally been aware of the necessity to look at the human person; Pope Francis does it from a very practical and pastoral approach. He mostly follows the final statements of the preceding Synods of Bishops. ${ }^{24}$

- $\mathrm{AL}$, chapter I (In the light of the Word)

This chapter, by referring to biblical passages, generally shows how the consciences of the faithful should be formed in the light of divine revelation, especially in matters of marriage and family life. The fruits of following conscience in this regard are positive and joyful, whereas the consequences of ignoring the divine plan of creation and salvation are sometimes disastrous and show a "path of suffering and blood" in history. ${ }^{25}$

- AL, chapter II (The experiences and challenges of families)

Among the people of today there are some concepts of individual freedom without acknowledging objective truth; there is an influence of relativism and subjectivism. This has consequences for marriage in its character of mutual obligation and faithfulness. Therefore, in AL 34 without using the term "conscience" - a special form of erroneous conscience is mentioned, namely the fundamental blindness for objective

24 Cf. Relatio Synodi of the Third Extraordinary General Assembly of the Synod of Bishops: The Pastoral Challenges of the Family in the Context of Evangelization (5-19.10.2014); Relatio finalis of the XIV Ordinary General Assembly of the Synod of Bishops: The Vocation and Mission of the Family in the Church and in the Contemporary World (4-25.10.2015).

25 Cf. AL 19-22. 
truth as such which is rooted in the denial to acknowledge God in his love and truth. ${ }^{26}$

A particularly important passage in AL 37 deals explicitly with conscience: "We also find it hard to make room for the consciences of the faithful, who very often respond as best they can to the Gospel amid their limitations, and are capable of carrying out their own discernment in complex situations. We have been called to form consciences, not to replace them." 27 This shows first a criticism of some wrong attitudes of persons who participate in the pastoral care of the Church, but it reminds also of the high esteem conscience should have in the Church. The authority of the Church (and in a special way the Magisterium of the Church, exercised by the Pope and bishops) rests on the authority of conscience, as blessed Cardinal Newman explained. ${ }^{28}$

The goal of this process of conscience formation is a greater conformity of conscience to the objective norms and criteria of morality. It is also a part of this process to acquire the virtue of prudence which enables people to judge more accurately about concrete matters of behavior and to decide correctly in everyday life. St Thomas states that it is more useful for man to be able to judge correctly under the guidance of prudence in concrete matters of acting than to have only a knowledge of moral values and principles. ${ }^{29}$

It is not enough for a human person to be guided in a prudent way by other people who are prudent. This is an imperfect state which might come first in child development. ${ }^{30}$ What is said here directly of prudence, can be applied indirectly to conscience in its prudential dimension. Therefore, the Church should exercise her authority not in the way to

26 „Ultimately, it is easy nowadays to confuse genuine freedom with the idea that each individual can act arbitrarily, as if there were no truths, values and principles to provide guidance, and everything were possible and permissible." (AL 34).

27 "Ad conscientias fingendas vocamur, non easdem ad commutandas." (AL 37).

${ }_{28}$ "Conscience is the aboriginal Vicar of Christ." - John Henry Cardinal Newman, Letter to the Duke of Norfolk, V, in: Certain Difficulties felt by Anglicans in Catholic Teaching II, London 1885,248 , quoted in CCC 1778.

29 Cf. Thomas Aquinas, Sententia libri Ethicorum, VI, 6, quoted in AL 304, footnote 348.

${ }^{30}$ Cf. Thomas Aquinas, STh I-II q.57 a.5 a.2. 
substitute the use of reason in the form of prudence in conscience but to enable people to use this faculty in a good way.

In the formation process of conscience, the contribution of the family is essential. "All these factors can inspire a positive and welcoming pastoral approach capable of helping couples to grow in appreciation of the demands of the Gospel," as AL 38 declares. AL recommends a pastoral approach which invites people to deepen their awareness of the requirements of the Gospel step by step, i.e. gradually. The law of graduality is important, first regarding the ability to fulfill the commandments of God, second in the way of a more and more perfect knowledge of this law and third regarding a growing ability to grasp the values on its basis. ${ }^{31}$

The Church clearly says that forcing the faithful against their conscience is not allowed, but some states and international organizations try to promote a politics of population reduction by introducing legal measures regarding abortion, sterilization and contraception which are against the dignity of the human person. There is a legitimate right of the spouses to exercise responsible parenthood according to the judgment of their conscience regarding the number of children..$^{32}$

This means, a well-formed conscience of the spouses can help to decide about the possible number of children. ${ }^{33}$ If conscience is not formed adequately, there will be wrong judgments in this case: either children are excluded for fear or egoistic reasons or a couple would think they should have as many children as possible without assessing and evaluating the conditions of the persons and the other relevant factors.

31 Of course, there is a great difference to the gradualness of law which cannot be accepted: cf. AL $293 \mathrm{ff}$.

32 "The upright consciences of spouses who have been generous in transmitting life may lead them, for sufficiently serious reasons, to limit the number of their children, yet precisely 'for the sake of this dignity of conscience, the Church strongly rejects the forced State intervention in favour of contraception, sterilization and even abortion'. Such measures are unacceptable even in places with high birth rates, yet also in countries with disturbingly low birth rates we see politicians encouraging them." - AL 42, quoting Relatio finalis 2015, no. 63.

33 Cf. Vatican Council II, Gaudium et spes, no. 50; HV 10. 
When families are in trouble, the Church should show them merciful understanding and accompaniment instead of indoctrination. They should be offered God's grace and the light of the Gospel. ${ }^{34}$ This has to do with the right formation of it in the context of a motivational process which is inspired by Divine grace.

There is a search in man for the values of marriage and family which the Church is asked to promote. So, conscience in the process of its formation is open to the truth of marriage and family. ${ }^{35}$

- AL, Chapter III (Looking to Jesus: The vocation of the family)

According to AL 79 there are complex situations in which the responsibility of the family members is not fully realised. The pastors, "for the sake of truth", should exercise "careful discernment of situations." 36 Even in these cases the pastors should clearly express the doctrine of the Church but in a way that avoids personal offenses. Conscience formation is therefore not easy, but it is necessary.

AL 83 defends conscientious objection in the case of legal measures regarding abortion or euthanasia.

AL 84 confirms that the education of children (and therefore also their conscience formation) is a primary duty and right of the parents. Other institutions may cooperate, but they do it in dependence from and in the name of the parents. This is especially true in sexual education. ${ }^{37}$

- AL, Chapter IV (Love in marriage)

Gradual growth in marital love is addressed. ${ }^{38}$ This requires attentiveness in conscience, and step by step the path of holiness will be followed by the spouses with the grace of God. The true maturity of conscience is realised in a vigilant, sensible, watchful conscience. It judges correctly and can distinguish in a profound way between morally grave and less grave matters. It is only possible in combination with the virtue

34 Cf. AL 49.

35 Cf. AL 57.

36 AL 79 quotes FC 84.

37 In AL 84, footnote 97, there is an explicit reference to: Pontifical Council for the Family, The Truth and Meaning of Human Sexuality, 8.12.1995, no. 23.

38 Cf. AL 120-122. 
of prudence. The soul and highest motivation of this elaborated conscience is in the love of God and neighbor. Love is not fearful but attentive.

- AL, Chapter V (Love made fruitful)

In education, the role of mother and father is equally important. ${ }^{39}$ In their love, the love of God the Father is represented and experienced. So, the child develops a sense of trust in reality ${ }^{40}$ the necessity of fighting for goods but also the acceptance of limitations; it is confirmed in its own value which is the basis of every value education and conscience formation. ${ }^{41}$ If parents are not able to give their children a good orientation, they cannot adequately develop their moral consciousness. ${ }^{42}$

Before receiving the body and blood of Christ in the Holy Eucharist, every faithful is asked to make a self-examination, including the social aspects of life, especially of openness for the poor (cf. 1 Cor 11:28). This should be done based on a well-formed conscience. ${ }^{43}$

The gap between the generations should be minimized by honoring the elderly people. This will be the positive answer to a "collapse of the certainties that shape our lives." ${ }^{44}$ In this way, such a deficit to learn from elderly people is a possible cause for a darkening or even for a blindness in the cognition of values in conscience.

- AL, Chapter VI (Some pastoral perspectives)

In her pastoral care for the families, the Church should offer values and so give an answer to the deepest desires of men and women, not only by talking about the normative dimension. This is an important part of conscience formation through the help of Church. Such values are the dignity of man and woman, their fulfillment in mutual love, community, and fruitfulness. ${ }^{45}$ The virtue of chastity should be strengthened. ${ }^{46}$

\footnotetext{
Cf. AL 172-177.

Cf. E. Erikson, Identity and the Life Cycle, New York 1959.

Cf. AL 175.

Cf. AL 176.

Cf. AL 185-186.

AL 193.

Cf. AL 201 and 205.

Cf. AL 206.
} 
Spiritual guidance and the sacrament of penance are important for conscience formation. ${ }^{47}$ Not the quantity of knowledge is essential but an inner taste of the truth in Christ, according to Saint Ignatius of Loyola; this has to do with the virtues which enable man with some connaturality regarding the good..$^{48}$ Not only doctrinal elements and spiritual resources should be offered, but practical ways and incarnated advices. ${ }^{49}$

The Word of God is the criterion of right judgment for the family members, i.e. conscience formation should be realised by listening to God's word or by reading Holy Scripture and by meditating it in union with the tradition of the Church and its Magisterium. ${ }^{50}$

- AL, chapter VII (Towards a better education of children)

In education, it is most important to form moral virtues: "The strengthening of the will and the repetition of specific actions are the building blocks of moral conduct; without the conscious, free and valued repetition of certain patterns of good behaviour, moral education does not take place. Mere desire, or an attraction to a certain value, is not enough to instil a virtue in the absence of those properly motivated acts." 51

Even if human conscience is right, not all will follow it: "Often we prove inconsistent in our own convictions, however firm they may be; even when our conscience dictates a clear moral decision, other factors sometimes prove more attractive and powerful." ${ }^{52}$

Moral education does not only mean to give information about right conduct but to enable the child to form her or his own judgment in conformity with the moral law and to motivate the child for acting in a morally good way from within..$^{33}$

Moral education "should also take place inductively, so that children can learn for themselves the importance of certain values, principles and

47 Cf. AL 204, 211.

48 Cf. AL 207.

49 Cf. AL 211; cf. AL 222.

50 Cf. AL 227.

$51 \quad$ AL 266.

52 AL 265.

53 Cf. AL 265-266. 
norms, rather than by imposing these as absolute and unquestionable truths. ${ }^{54}$ The life of virtue should be strengthened. ${ }^{55}$

Some limitations in making the right choices have their origin in an imperfect moral development. ${ }^{56}$ This is connected with deficits in moral judgment and could be a possible source of error in conscience. Good examples are most important to see the actualization of moral values. ${ }^{57}$ The moral difference in free and voluntary acts must be acknowledged: not every voluntary act is really free..$^{58}$

In school education, there is a right of the Church to teach the Catholic doctrine and to establish Catholic schools; there is also a right of educators of conscientious objection if possibly some state programmes would present ideas against their Christian principles. ${ }^{59}$

- AL, Chapter VIII (Accompanying, discerning and integrating weakness)

The Church has to apply pastoral discernment "in those situations which do not yet or no longer correspond to her teaching on marriage." ${ }^{60}$ To help the persons, the pastors must search for "constructive elements" ${ }_{11}$ "in their lives that can lead to a greater openness to the Gospel of marriage in its fullness." ${ }^{62}$ There is a need "to identify elements that can foster evangelization and human and spiritual growth". ${ }^{63}$ This is exemplified in the following way, regarding unions of persons who are not married validly at their present state: "when such unions attain a particular stability, legally recognized, are characterized by deep affection and responsibility for their offspring, and demonstrate an ability to overcome trials, they can provide occasions for pastoral care with a view to the eventual celebration of the sacrament of marriage." ${ }_{64}$
AL 264.
Cf. AL 267.
Cf. AL 269.
Cf. AL 272.
Cf. AL 273.
Cf. AL 279.
AL 292.
AL 292.
AL 293.
AL 293.
4 AL 293. 
What does this mean for conscience formation? Conscience might be partly erroneous, but it is also a question of some moral weakness if the Christian vision of marriage and family is not realised but contradicted more or less. The pastoral task is not to condemn persons but to save them in Christ (cf. Jn 12:47). The dignity of the persons has to be respected, and all the good which is already realised is recognized in its dynamics. By prayer and in openness for God's grace, the clarity in conscience is expected to grow on these steps which can and should be followed on the way to holiness. The positive elements have to be strengthened; this will result possibly in a process of conversion to God who wills to save all men and women and to lead them to the full cognition of truth (cf. 1 Tim 2:4).

AL confirms that there is not a "gradualness of law" but a "law of gradualness:"

For the law is itself a gift of God which points out the way, a gift for everyone without exception; it can be followed with the help of grace, even though each human being "advances gradually with the progressive integration of the gifts of God and the demands of God's definitive and absolute love in his or her entire personal and social life." 65

In so called "irregular" situations, there might be the case of a couple, who stay together for the sake of children (or other graves reasons), "without feeling in conscience that one would fall into new sins." Other couples "are sometimes subjectively certain in conscience that their previous and irreparably broken marriage had never been valid." ${ }^{66}$ Conscience might be erroneous but without any subjective guilt; conscience could also be in a partially right judgment. The pastors are asked to apply the right form of discernment helping the couples to ' '... understand the divine pedagogy of grace in their lives and offering them assistance so they can reach the fullness of God's plan for them', something which is always possible by the power of the Holy Spirit." ${ }^{\prime 7}$ The "forum internum"

65 AL 295, with reference to FC 9 and FC 34.

66 AL 298.

67 AL 297. 
and "forum externum" should be distinguished, which is also relevant in the case of receiving the Holy Sacraments. Something can be already clear in the "forum internum" which has not yet been revealed in the "forum externum" (e.g. the firm intention of living in sexual abstinence by respecting the marital bond). The gap in questions of validity of sacramental marriage between subjective judgments in conscience and the objective declaration of nullity by an Ecclesiastical court should be minimized; Pope Francis has tried to improve the canonical processes. ${ }^{68}$

A possible cause of error in conscience is addressed by AL: Problems in the cognition of truth in conscience can be due to the fact that man doesn't know a moral norm or commandment, but there might be also great difficulties to understand the values which are protected by the moral norm. ${ }^{69}$ A correctly formed conscience in combination with pastoral care can help to make the necessary distinctions between the objective demands of morality and subjective responsibility, since there are various factors which could reduce personal freedom in doing the good and avoiding evil. ${ }^{70}$

The importance of conscience formation under the guidance of the pastors of the Church is emphasized. But on this precondition, conscience should be taken as fully relevant, even in situations when the present state of life is not in full conformity with moral law. Since then conscience shows - in the process of gradual conversion - the next step to be followed towards the fulfilment of God's law. There might be limitations for some people to realise the demands of morality, but there is never a situation without hope. Divine grace invites them to follow the path of holiness:

68 Cf. Francis, Apostolic Letter Motu proprio Mitis iudex Dominus Iesus by which the canons of the code of Canon Law pertaining to cases regarding the nullity of marriage are reformed, 15.08.2015; Francis, Apostolic Letter Motu proprio Mitis et Misericors Iesus by which the canons of the code of Canons of Eastern Churches pertaining to cases regarding the nullity of marriage are reformed, 15.08.2015. Cf. L. Müller, Das kirchliche Ehenichtigkeitsverfahren nach der Reform 2015, Paderborn 2017.

69 Cf. AL 301 with reference to FC 33.

70 Cf. AL 302. 
Recognizing the influence of such concrete factors, we can add that individual conscience needs to be better incorporated into the Church's praxis in certain situations which do not objectively embody our understanding of marriage. Naturally, every effort should be made to encourage the development of an enlightened conscience, formed and guided by the responsible and serious discernment of one's pastor, and to encourage an ever greater trust in God's grace. Yet conscience can do more than recognize that a given situation does not correspond objectively to the overall demands of the Gospel. It can also recognize with sincerity and honesty what for now is the most generous response which can be given to God, and come to see with a certain moral security that it is what God himself is asking amid the concrete complexity of one's limits, while yet not fully the objective ideal. In any event, let us recall that this discernment is dynamic; it must remain ever open to new stages of growth and to new decisions which can enable the ideal to be more fully realized. ${ }^{71}$

The text is not a justification of error in conscience and of a self-chosen exception from the moral law. It is a challenge for both pastors and the faithful living in such a state to open themselves dynamically for the truth of Christ. Therefore, in a gradual process of conversion they will be able to do the good and to develop a right judgment of conscience with is in conformity with the law of God.

The normative aspects of Christian life are addressed in AL 304-306. In concrete life, general moral norms can only be applied with prudent consideration. Pope Francis presupposes such norms which do not forbid intrinsically evil acts, since in such a case it is clear that there is no way of exceptions..$^{72}$ The subjective situation of persons who life in an objectively sinful state is not always that of imputable mortal sin. They can be excused partially or totally insofar as there might be circumstances which reduce their subjective guilt. Therefore, they can grow in grace and be living members of the Church who should offer them some help which might include even the sacramental dimension - of course, always under the regular conditions clarified by the Church. ${ }^{73}$ In any way, those

71 AL 303.

72 Cf. John Paul II, VS 56. Pope Francis in his Encyclical letter Fratelli tutti on Fraternity and Social Friendship from October $3^{\text {rd }}, 2020$, in no. 209 explicitly refers to VS 96 in the case of "moral norms prohibiting intrinsic evil".

73 Cf. AL 305 with footnote 351: "In certain cases, this can include the help of the sacraments." A Magisterial interpretation of these aspects has been given by Pope Francis 
in such a state and all the other faithful should realise the way of love for their neighbour since love takes away sins.

Pastoral care has to apply truth and mercy, especially with those living in irregular situations. ${ }^{74}$ "To show understanding in the face of exceptional situations never implies dimming the light of the fuller ideal, or proposing less than what Jesus offers to the human being." 75 To announce and explain the truth about marriage and family is in service of the formation of conscience of the faithful.

"The teaching of moral theology should not fail to incorporate these considerations, for although it is quite true that concern must be shown for the integrity of the Church's moral teaching, special care should always be shown to emphasize and encourage the highest and most central values of the Gospel, particularly the primacy of charity as a response to the completely gratuitous offer of God's love."76 The pastors should offer the light of the Gospel to every human conscience (cf. 2 Cor 4:2). ${ }^{77}$

\section{Conclusion}

In summary, AL shows that in spite of an erroneous conscience there is a dynamic in life which allows - under the influence of grace - an ongoing maturation and growth and makes possible even a fundamental conversion to God. Erroneous conscience is not seen as a static reality but as a starting point for future development towards truth.

As this analysis might have shown, the Church gives a high estimation to personal conscience. Conscience is a subjective faculty in the

in a letter to Argentinian bishops: Franciscus, Epistula Apostolica ad Excellentissimum Dominum Sergium Alfredum Fenoy, delegatum Regionis Pastoralis Bonaërensis, necnon adiunctum documentum (de praecipuis rationibus usui capitis VIII Adhortationis post-synodalis Amoris laetitia), 5.09.2016, AAS 108 (2016), p. 1071-1072. Cf. J. Spindelböck, Die „Amoris latitia“ - Kontroverse. Ein moraltheologischer Beitrag zur formalen und inhaltlichen Klärung, in: Glaube und Kirche in Zeiten des Umbruchs. Festschrift für Josef Kreiml, Hrsg. V. Neumann, J. Spindelböck, S. Bonk, unter Mitarbeit von S. Biber, Regensburg 2018, p. 739-755.

\footnotetext{
74 Cf. AL 307-312.

75 AL 307.

76 AL 311.

77 Cf. AL 312.
} 
intellectual soul which is oriented to the knowledge of the truth in moral law. It needs constant formation, and the "splendor of truth" originating in God's wisdom and love is an affirmation of the personal dignity of man.

\section{Bibliography}

\section{Magisterial Documents (chronologically)}

Vatican Council II, Dogmatic Constitution on the Church Lumen gentium, 21.11.1964, http://www.vatican.va/archive/hist_councils/ii_vatican_council/documents/vat-ii_const_19641121_lumen-gentium_en.html (26.08.2021).

Vatican Council II, Pastoral Constitution on the Church in the modern world Gaudium et spes, 7.12.1965, http://www.vatican.va/archive/hist_councils/ii_vatican_council/ documents/vat-ii_cons_19651207_gaudium-et-spes_en.html (26.08.2021).

Paul VI, Encyclical letter Humanae vitae on the regulation of birth, 25.07.1968, Latin text in: AAS 60 (1968), 481-503, English translation in The Pope Speaks, 13 (Fall. 1969), 329-46, https://w2.vatican.va/content/paul-vi/en/encyclicals/documents/ hf_p-vi_enc_25071968_humanae-vitae.html (26.08.2021).

Deutsche Bischofskonferenz, Königsteiner Erklärung, 30.08.1968, http://www.kathpedia.com/index.php/K\%C3\%B6nigsteiner_Erkl\%C3\%A4rung_(Wortla) (26.08.2021).

Österreichische Bischofskonferenz, Maria Troster Erklärung, 22.08.1968, https:// www.stjosef.at/dokumente/oesterreichische_bischofserklaerungen_humanae_vitae. htm (26.08.2021).

John Paul II, Apostolic Exhortation Familiaris consortio on the Role of the Christian Family in the Modern World, 22.11.1981, https://www.vatican.va/content/ john-paul-ii/en/apost_exhortations/documents/hf_jp-ii_exh_19811122_familiaris-consortio.html (26.08.2021).

John Paul II, Encyclical letter Veritatis splendor regarding certain fundamental questions of the Church's moral teaching, August $6^{\text {th }}, 1993$, Latin text in AAS 85 (1993), 1133-1228, English translation http://w2.vatican.va/content/john-paul-ii/en/encyclicals/documents/hf_jp-ii_enc_06081993_veritatis-splendor.html (26.08.2021).

Pontifical Council for the Family, The Truth and Meaning of Human Sexuality. Guidelines for Education within the Family, 8.12.1995, https://www.vatican.va/roman_curia/ pontifical_councils/family/documents/rc_pc_family_doc_08121995_human-sexuality_en.html (26.08.2021).

Catechism of the Catholic Church, Second Edition, Vatican 1997, https://www.scborromeo2.org/catechism-of-the-catholic-church (26.08.2021).

Benedict XVI, Address to the Roman Curia offering them his Christmas greetings, 22.12.2005, http://w2.vatican.va/content/benedict-xvi/en/speeches/2005/december/documents/hf_ben_xvi_spe_20051222_roman-curia.html (26.08.2021).

Relatio Synodi of the Third Extraordinary General Assembly of the Synod of Bishops: The Pastoral Challenges of the Family in the Context of Evangelization (5-19.10.2014), http:// 
www.vatican.va/roman_curia/synod/documents/rc_synod_doc_20141018_relatio-synodi-familia_en.html (26.08.2021).

Relatio finalis of the XIV Ordinary General Assembly of the Synod of Bishops: The Vocation and Mission of the Family in the Church and in the Contemporary World (4-25 October 2015), http://www.vatican.va/roman_curia/synod/documents/rc_synod_ doc_20151026_relazione-finale-xiv-assemblea_en.html (26.08.2021).

Francis, Apostolic Letter Motu proprio Mitis iudex Dominus Iesus by which the canons of the code of Canon Law pertaining to cases regarding the nullity of marriage are reformed, 15.08.2015.

Francis, Apostolic Letter Motu proprio Mitiset Misericors Iesus by which the canons of the code of Canons of Eastern Churches pertaining to cases regarding the nullity of marriage are reformed, 15.08.2015.

Francis, Post-synodal Apostolic Exhortation Amoris laetitia on love in the family, 19.03.2016, Latin text in: AAS 108 (2016), p. 311-446, English translation http:// w2.vatican.va/content/dam/francesco/pdf/apost_exhortations/documents/papa-francesco_esortazione-ap_20160319_amoris-laetitia_en.pdf (26.08.2021).

Francis, Encyclical letter Fratelli tutti on Fraternity and Social Friendship, 3.10.2020, https://www.vatican.va/content/francesco/en/encyclicals/documents/papa-francesco_20201003_enciclica-fratelli-tutti.html (26.08.2021).

Franciscus, Epistula Apostolica ad Excellentissimum Dominum Sergium Alfredum Fenoy, delegatum Regionis Pastoralis Bonaërensis, necnon adiunctum documentum (de praecipuis rationibus usui capitis VIII Adhortationis post-synodalis Amoris laetitia), 5.08.2016, AAS 108 (2016), p. 1071-1072.

\section{Literature}

Ebner K. / Mesner M., Attempted Disobedience: "Humanae vitae" in West Germany and Austria, in: The Schism of "68. Catholicism, Contraception and "Humanae vitae" in Europe, 1945-1975, eds. A. Harris, London 2018, p. 121-158.

Erikson E., Identity and the Life Cycle, New York 1959.

Hildebrand Dietrich von, Ethik, Stuttgart o.J., 2. Auflage.

Hildebrand Dietrich von, Sittlichkeit und ethische Werterkenntnis. Eine Untersuchung über ethische Strukturprobleme, Vallendar-Schönstatt 1982.

Müller L., Daskirchliche Ehenichtigkeitsverfahren nach der Reform 2015, Paderborn 2017.

Thomas Aquinas, Summa theologiae, https://aquinas.cc (26.08.2021).

Thomas Aquinas, Sententia libri Ethicorum, https://www.corpusthomisticum.org/ iopera.html (26.08.2021).

Schockenhoff E., Wie gewiss ist das Gewissen? Eine ethische Orientierung, Freiburg 2003, ebook 2016.

Schulz Ch., Die Enzyklika „Humanae vitae "im Lichte von „Veritatis splendor”. Verantwortete Elternschaft als Anwendungsfall der Grundlagen der katholischen Morallehre, St. Ottilien 2008.

Spindelböck J., Gewissen und Gewissensirrtum aus ethischer Perspektive, „Imago hominis“ 25 (2018) H. 1, p. 35-45. 
Spindelböck J., Die „Amoris loetitia“ - Kontroverse. Ein moraltheologischer Beitrag zur formalen und inhaltlichen Klärung, in: Glaube und Kirche in Zeiten des Umbruchs. Festschrift für Josef Kreiml, Hrsg. V. Neumann, J. Spindelböck, S. Bonk, unter Mitarbeit von S. Biber, Regensburg 2018, p. 739-755.

\section{Other sources}

TV: Joseph Cardinal Ratzinger, Dokumentation „Die geheime Inquisition - Feuer des Glaubens“ (1/3), ORF III, 31.10.2018, 12.55-13.49 Uhr. 